\title{
ИСПОЛЬЗОВАНИЕ МЕТОДА МОЛЕКУЛЯРНЫХ ОРБИТАЛЕЙ В ПРОГНОЗЕ АНТИГЛИКИРУЮЩЕЙ АКТИВНОСТИ
}

\author{
Р.А. Литвинов ${ }^{1,2}$, П.М. Васильев ${ }^{1}$, А.Н. Кочетков \\ ${ }^{1}$ НЦИЛС, ФГБОУ ВО ВолгГМУ Минздрава России, \\ 400131, Россия, г. Волгоград, площадь Павших Борцов, д. 1. \\ 2Лаборатория экспериментальной фармакологии, ГБУ Волгоградский медицинский \\ научный центр, 400131, Россия, г. Волгоград, площадь Павших Борцов, д. 1.
}

DOI: 10.19163/MedChemRussia2021-2021-96

E-mail: litvinov.volggmu@mail.ru

Гликирование представляет собой комплексную биохимическую реакцию, протекающую по множеству механизмов, дающую более 20 конечных продуктов (КПГ). Медицинская значимость гликирования обусловлена участием КПГ в патогенезе поздних осложнений сахарного диабета, болезней пожилого возраста и других заболеваний.

Ранее была показана возможность построения классификационной QSARмодели для прогноза уровня антигликирующей активности на основе энергий граничных молекулярных орбиталей (МО). Подход базируется на том, что: (i) анализ энергий МО позволяет прогнозировать (био)химическую реакционную способность соединений; (iі) гликирование есть (био)химическая реакция. В ходе предшествующих исследований различнозамещенных производных азолоазина, тимина, урацила и др. [1-4] установлено, что: (i) энергии граничных и близких к ним MO, а также величина энергетической щели есть репрезентативный набор данных для построения прогнозной зависимости антигликирующей активности от расчетных параметров соединений; (iі) надежной моделью прогноза является нейросетевая модель. Установлены критические направления повышения надежности прогнозной модели: (i) расширение числа используемых МO; (ii) применение базисов расщепленной валентности (ab initio); (iii) использование консенсусного ансамблевого нейросетевого прогноза; (iv) обучение нейросетей на гетерогенных выборках соединений.

Работа проведена при финансовой поддержке гранта Президента Российской Федерации для поддержки молодых ученых - кандидатов наук МК-1887.2020.7.

\section{Литература}

[1] Litvinov R.A., Shamshina D.D., Kalenova M.Y. et al. Russ. J. Bioorganic Chem. 2020, 46 (6), 1278-84.

[2] Васильев П.М., Спасов А.А., Кочетков А.Н., Литвинов Р.А. Сборник материалов международной конференции Параллельные вычислительные технологии, 2021, 186-193.

[3] Литвинов Р.А., Лисина С.В., Брель А.К. и др. Сборник материалов VI междисциплинарной конференции Молекулярные и Биологические аспекты Химии, Фармацевтики и Фармакологии. Москва, 2020, 62.

[4] Литвинов Р.А., Васильев П.М., Дрокин Р.А. и др. Сборник материалов XXVII симпозиума Биоинформатика и компьютерное конструирование лекарств, 2021, 31.

$$
-96-
$$

